\title{
ENEA RADIOCARBON MEASUREMENTS II
}

\author{
Giuseppe Magnani ${ }^{1} \bullet$ Paolo Bartolomei • Teresa La Torretta • Ernesto Claudio Marino \\ ENEA, Radiocarbon Laboratory, Via dei Colli 16, 40136 Bologna, Italy.
}

ABSTRACT. This paper includes determinations of geological samples coming from the Emilia Romagna region (northern Italy) performed at the ENEA Radiocarbon Laboratory. These analyses were executed as part of the Geological Cartography (CARG) project aimed to realize a new Italian Geological Map.

\section{INTRODUCTION}

Knowledge of the geology and the processes that caused the evolution of a territory is an important issue recognized by many public officials. This knowledge is fundamental for proper management of a territory for urban, industrial, and tourism purposes and for a balanced, rational use of the area's natural resources.

Knowledge of geomorphologic and geodynamic processes constitutes a starting point for a prevention and protection policy for developed areas and infrastructures from hydrogeological risk, for which Italy has invested many resources in the last decades. The survey activities of a new geological map began in the early 1990s with the Geological Cartography (CARG) project, which aims to realize a new Italian Geological Map.

The CARG project is a national program, coordinated by the Italian Geological Survey, that foresees the realization of a new Italian Geological Map and its digital database at 1:50,000 scale. This project had been previously divided into 3 separately financed projects. The Emilia Romagna geological map was partially completed by the "Geological Seismic and Soil Survey" of the Emilia Romagna region (in northern Italy) with the collaboration of the ENEA Radiocarbon Laboratory. In particular, the Emilia Romagna territory was divided into 61 different areas (Figure 1) where samples (soil, wood, and peat) were collected at different depths. The ENEA Radiocarbon Laboratory dated the samples from the Emilia Romagna Plain (southern part of the Po Plain, in the Emilia Romagna region). This paper reports determinations of geological samples collected and analyzed in the period 1994-2004.

\section{EXPERIMENTAL METHOD}

Samples of soil, wood, and peat were treated following the method reported by Magnani et al. (2006). Age calculations are based on the Libby half-life of $5568 \mathrm{yr}$ and are expressed in ${ }^{14} \mathrm{C}$ yr relative to AD 1950. Ages and standard deviations (1- $\sigma$ error) of samples are adjusted for stable isotope fractionation to a normalized concentration ratio $\left(\delta^{13} \mathrm{C}=-25 \%\right.$ ) according to recommendations reported by Stuiver and Polach (1977), using default $\delta^{13} \mathrm{C}$ values.

Calibrated ages are calculated from rounded ${ }^{14} \mathrm{C}$ conventional ages using the software program OxCal v 3.10 (Bronk Ramsey 2005) with $1-\sigma$ error (68.2\% confidence level). When several calendar age ranges are obtained, a probability for each interval is given. Probabilities $<5 \%$ are omitted.

\section{RESULTS AND DISCUSSION}

The Po Plain is an area with high environmental risk: it can be defined as a seismic area, for its geologic nature is subject to subsidence phenomena; the water-bearing strata are in extremely vulnera-

${ }^{1}$ Corresponding author. Email: giuseppe.magnani@bologna.enea.it. 


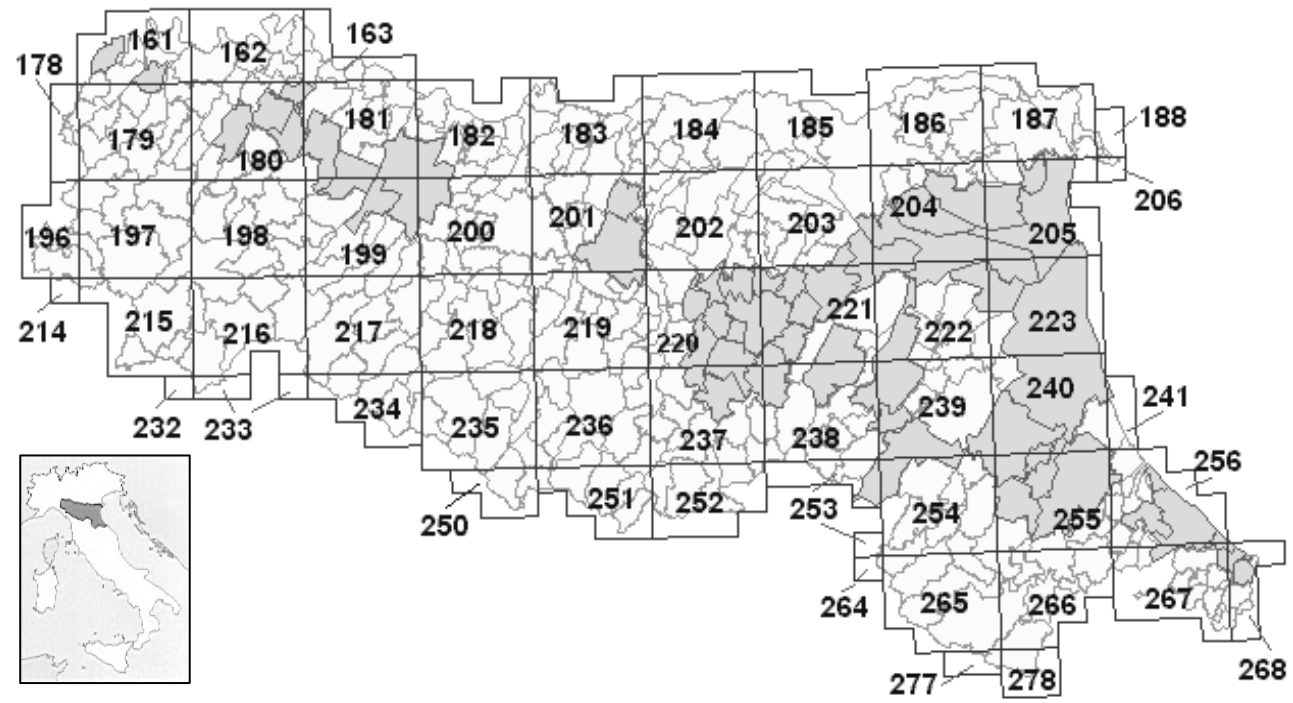

Figure 1 Emilia Romagna territory divided into 61 sheets that constitute the new geological map of this region

ble zones; and the exploitation of these strata has often caused serious problems, especially in the increase of subsidence phenomena.

The main objective of the geologic cartography of the Po Plain is to study the distribution and geometry of its sediments (gravelly and sandy), aiming to define the water volume that saturates them and becomes available for certain uses. This distribution pattern is, moreover, indispensable when estimating the modes and times of recharge of the various characterized strata. This knowledge allows researchers to plan every relative study regarding pollution of these strata, and to define and order the use of water resources without creating deficiencies in the hydrogeological balance. To accomplish this objective, an integrated study of the alluvial deposits, both aboveground and buried, was necessary to better understand the evolutionary history that, via the raising of the Apennines and the subsidence of the plain, has affected the actual configuration of this plain. Only after clearing the stratigraphy was it possible to begin the work of geologic cartography with the aim of describing the spatial fluctuations of the alluvial sediment that constitute the surface and subsoil of the Po Plain.

On the basis of the considerations above, it was clear that ${ }^{14} \mathrm{C}$ determinations would be particularly useful for stratigraphic characterization of the soils. Samples were always collected by the Geological Seismic and Soil Survey (GSSS) of the Emilia Romagna region following the procedures reported by Bini et al. (1999). Age determinations, listed in the Appendix, together with investigations of the underground formations (continuous, cored bore-holes, penetrometric tests, and highresolution seismic analysis) and other laboratory tests (pollen analyses to establish the paleoclimates, geotechnical tests, and petrographic analyses) permitted compilation of the definitive map. In Figure 2, a geological map of sheet 256 is given as an example (Regione Emilia-Romagna e Servizio Geologico d'Italia 2005). In addition, samples were collected from several sites at different depths in order to evaluate the correlation between depth and ${ }^{14} \mathrm{C}$ age. Results reported in Figure 3 show a very strong correlation for all the series where this analysis was possible, and suggests that the basic integrity of the deposits is intact. Furthermore, a rough estimation of the accretion rate of the Emilia Romagna Plain could be extracted by a linear regression of the ages. Data reported in Table 1 show that the highest accretion rate $(19.6 \mathrm{~m} / \mathrm{kyr})$ was found close to the Adriatic Sea (Bellaria series). Additional detailed analyses of these values revealed that the lowest value, $0.4 \mathrm{~m} / \mathrm{kyr}$, referred to the 
wood samples (Boretto series), while an accretion rate of $2.6 \mathrm{~m} / \mathrm{kyr}$ was found relatively close to the sea (Ravenna series, sheet 223). The remaining accretion rate values, ranging from 0.8 to $1.6 \mathrm{~m} / \mathrm{kyr}$, were consistent with the value $(1.2 \mathrm{~m} / \mathrm{kyr})$ determined by Amorosi et al. (1996) in the Bologna floodplain (sheet 220 in Figure 1).

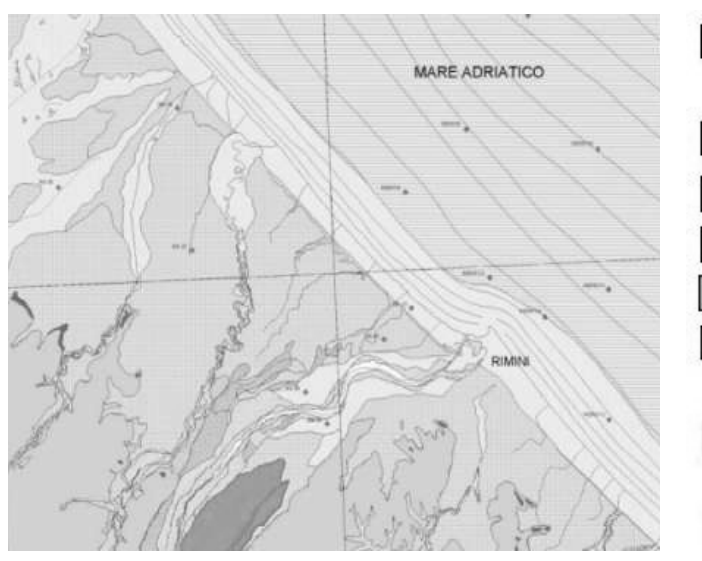

Sistemi deposizionali e litologie

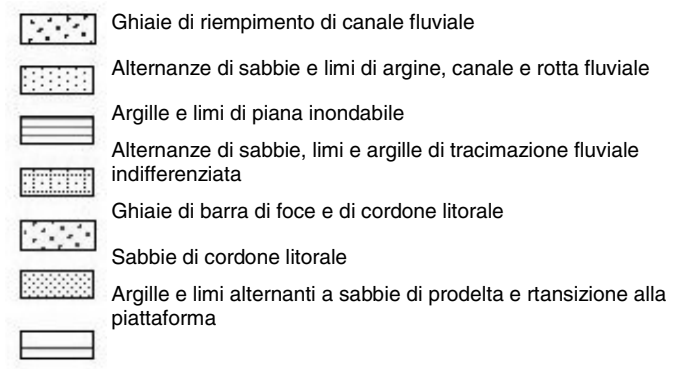

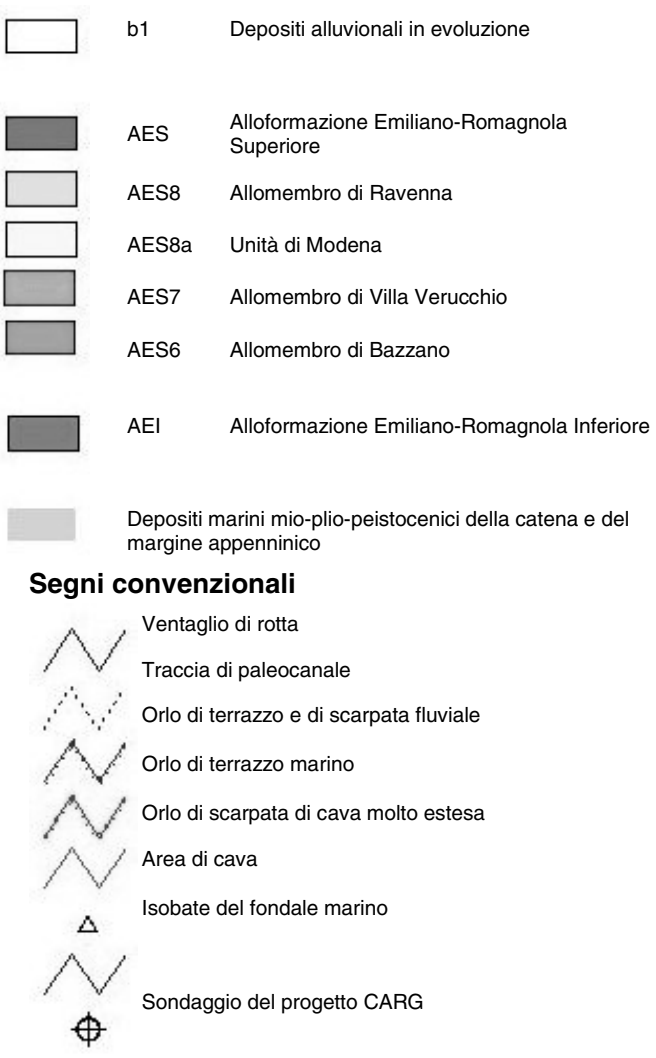

Figure 2 Geological map of the sheet 256 (Regione Emilia-Romagna e Servizio Geologico d'Italia 2005)

Table 1 Accretion rate estimation based on the linear regressions reported in Figure 3.

\begin{tabular}{lllllllll}
\hline & $\begin{array}{l}\text { Bellaria } \\
\text { series }\end{array}$ & $\begin{array}{l}\text { Stradella } \\
\text { series }\end{array}$ & $\begin{array}{l}\text { Fidenza } \\
\text { series }\end{array}$ & $\begin{array}{l}\text { Ravenna } \\
\text { series }\end{array}$ & $\begin{array}{l}\text { Cesena } \\
\text { series }\end{array}$ & $\begin{array}{l}\text { Soliera } \\
\text { series }\end{array}$ & $\begin{array}{l}\text { Argenta } \\
\text { series }\end{array}$ & $\begin{array}{l}\text { Boretto } \\
\text { series }\end{array}$ \\
\hline $\begin{array}{l}\text { Accretion } \\
\text { rate }(\mathrm{m} / \mathrm{kyr})\end{array}$ & 19.6 & 1.1 & 0.8 & $\begin{array}{l}2.6 \text { (sheet 223) } \\
1.6 \text { (sheet 240-S5) }\end{array}$ & 0.8 & 1.0 & 0.8 & 0.4 \\
& & & & & & & \\
& & & & & & & & \\
\end{tabular}

\section{CONCLUSION}

Ages for samples collected in the southern part of the Po Plain (Emilia Romagna Plain) represented a decisive contribution to the compilation of the geological map of this area. The Geological Seismic and Soil Survey of the Emilia Romagna region used these dates to complete some of the 61 sheets of the Emilia Romagna geological map at 1:50,000 scale. Analysis of the ${ }^{14} \mathrm{C}$ determinations showed a strong correlation between depth and age for all series dated, with an accretion rate in the range $0.4-19.6 \mathrm{~m} / \mathrm{kyr}$. 

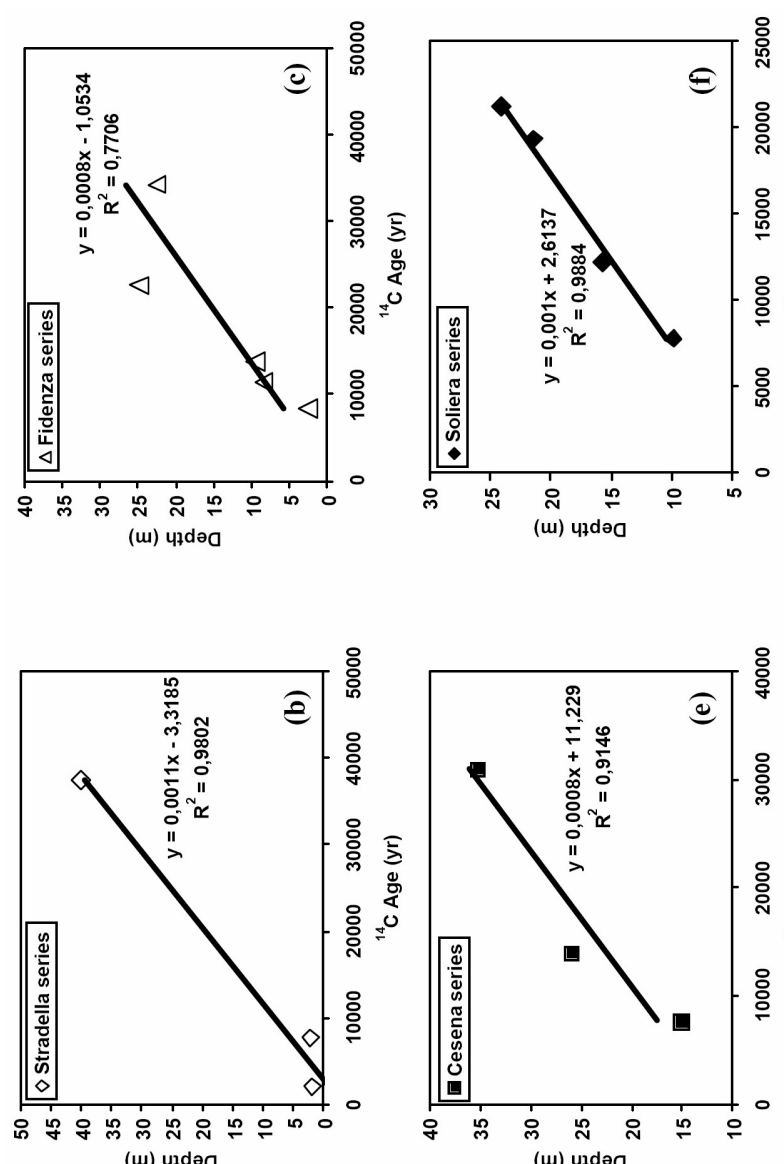

(U) yłdad
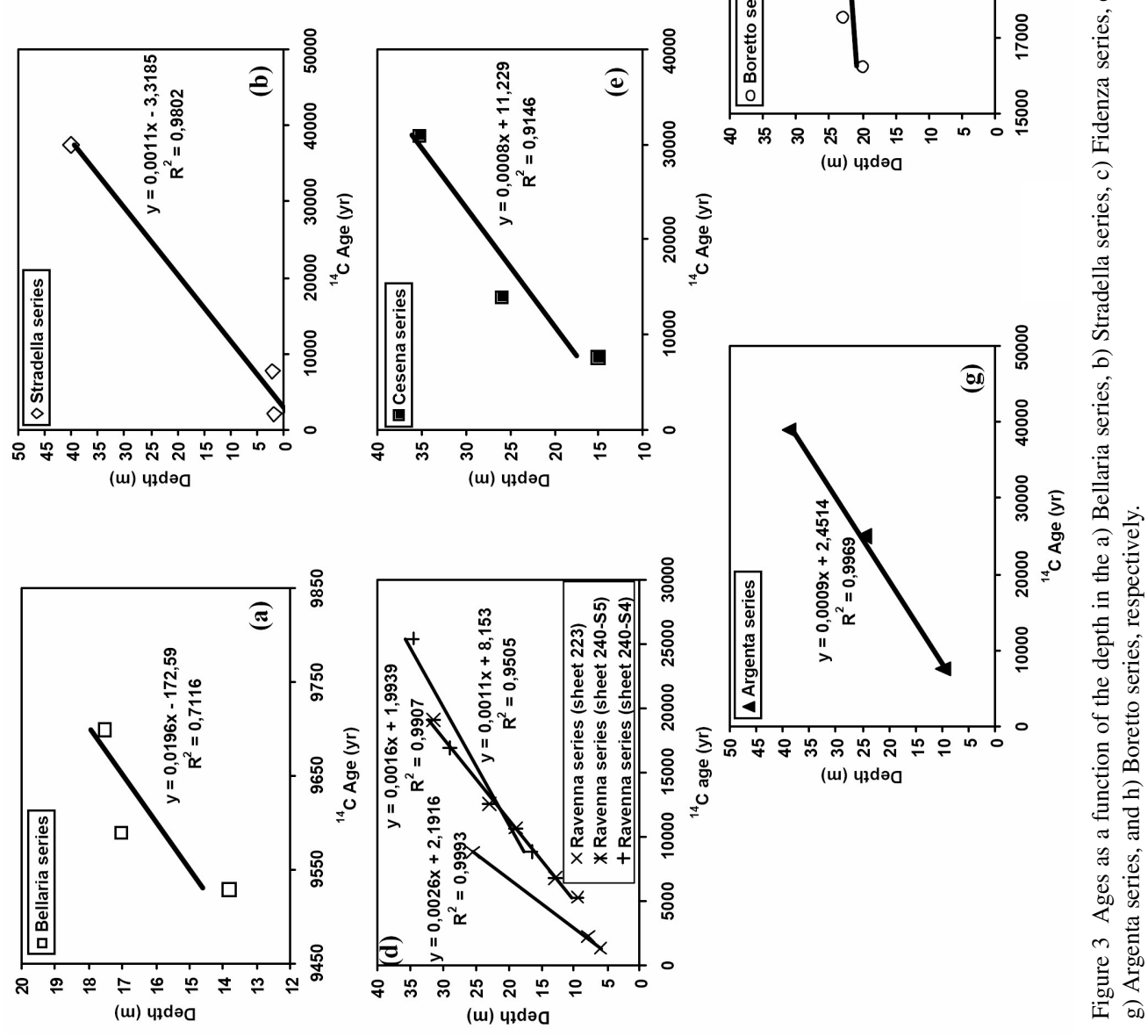


\section{REFERENCES}

Amorosi A, Farina M, Severi P, Preti D, Caporale L, Di Dio G. 1996. Genetically related alluvial deposits across active fault zones: an example of alluvial fanterrace correlation from the upper Quaternary of the southern Po Basin, Italy. Sedimentary Geology 102: 275-95.

Bini A, Carraro F, Ricci Lucchi F, Severi P. 1999. Guide to the survey and mapping of Italy's geological map [WWW document]. Geological Seismic and Soil Survey of the Emilia Romagna region. <http://www.regione.emilia-romagna.it/geologia/e_cart1.htm\#gui>.

Bronk Ramsey C. 2005. OxCal program v 3.10 [software and online manual]. URL: http://www.rlaha.ox.ac.uk/ oxcal/oxcal.htm.

Gupta SK, Polach HA. 1985. Radiocarbon dating practices at ANU. Canberra: Radiocarbon Laboratory, Research School of Pacific Studies, Australian National University [ANU]. p 72-5.

Magnani G, Bartolomei P, La Torretta T, Marino EC, Govoni C. 2006. ENEA radiocarbon measurements I. Radiocarbon 48(1):167-75.

Regione Emilia-Romagna e Servizio Geologico d'Italia. 2005. Carta Geologica d'Italia in scala 1:50.000, Foglio 256, Rimini.

Stuiver M, Polach HA. 1977. Discussion: reporting of ${ }^{14} \mathrm{C}$ data. Radiocarbon 19(3):355-63.

\section{APPENDIX: ${ }^{14} \mathrm{C}$ RESULTS}

\section{Bellaria Series}

Samples from Bellaria (Rimini, Italy) $\left(44^{\circ} 08^{\prime} \mathrm{N}, 12^{\circ} 29^{\prime} \mathrm{E}\right)$ were collected and submitted in 1994 by P Severi, Geological Seismic and Soil Survey of the Emilia Romagna region (hereafter GSSSERR), Bologna.

ENEA-411. BELLARIA 1

$9590 \pm 100$

Soil, $17.0 \mathrm{~m}$ depth (9160-8820 cal BC, 68.2\%).

ENEA-412. BELLARIA 2

$9530 \pm 70$

Soil, 13.8 m depth (9130-9000 cal BC, 30.7\%; 8920-8760 cal BC, 37.5\%).

ENEA-413. BELLARIA 3

$9700 \pm 100$

Soil, 17.5 m depth (9290-9110 cal BC, 42.8\%; 9010-8910 cal BC, 18.9\%; 8900-8850 cal BC, $6.5 \%)$.

ENEA-414. BELLARIA 4

$9740 \pm 300$

Soil, $13.5 \mathrm{~m}$ depth (9700-8600 cal BC, 68.2\%).

Comment: Ages were used for sheet 256 of the map in Figure 1. Correlation between depth and age is reported in Figure 3a.

\section{Piacenza Series}

Samples were collected and submitted in 1995 by P Severi (GSSSERR).

ENEA-424. PC 180 S8-C1

Background

Soil from Carpaneto Piacentino (Piacenza, Italy) $\left(44^{\circ} 53^{\prime} \mathrm{N}, 9^{\circ} 47^{\prime} \mathrm{E}\right), 38.4 \mathrm{~m}$ depth.

ENEA-425. PC 180 S4-C1

$37,600 \pm 3000$

Soil from Alseno (Piacenza) $\left(44^{\circ} 53^{\prime} \mathrm{N}, 9^{\circ} 58^{\prime} \mathrm{E}\right), 12.5 \mathrm{~m}$ depth.

ENEA-432. PC 180 S5-C1 Bis

$32,800 \pm 1600$

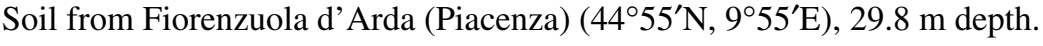

Comment: Ages were used for sheet 180 of the map in Figure 1. 


\section{Stradella Series}

Samples from Stradella (Parma) $\left(44^{\circ} 45^{\prime} \mathrm{N}, 10^{\circ} 15^{\prime} \mathrm{E}\right)$ were collected and submitted in 1995 by P Severi (GSSSERR).

ENEA-426. Stradella Est C1

$2030 \pm 100$

Soil, $1.8 \mathrm{~m}$ depth (180 cal BC-cal AD 70, 68.2\%).

ENEA-427. Stradella Est C2

$7640 \pm 110$

Soil, $2.1 \mathrm{~m}$ depth (6610-6400 cal BC, 68.2\%).

ENEA-428. Stradella Est C3

$37,400 \pm 1500$

Soil, $40.0 \mathrm{~m}$ depth.

Comment: Ages were used for sheet 199 of the map in Figure 1. Correlation between depth and age is reported in Figure $3 b$.

\section{Fidenza Series}

Samples from Fidenza $\left(44^{\circ} 51^{\prime} \mathrm{N}, 10^{\circ} 03^{\prime} \mathrm{E}\right)$ were collected and submitted in 1995 by $\mathrm{P}$ Severi (GSSSERR).

ENEA-429. PR181 S2 C3

$11,350 \pm 300$

Soil from Fidenza, 8.3 m depth (11,550-10,950 cal BC, 68.2\%).

ENEA-430. PR181 S2 C4

$22,600 \pm 900$

Soil, $24.8 \mathrm{~m}$ depth.

ENEA-442. Scavo Svincolo

$8340 \pm 130$

Soil, 2.5 m depth (7540-7290 cal BC, 58.6\%; 7230-7190 cal BC, 6.8\%).

ENEA-550. F181n1

$13,800 \pm 220$

Soil, $9.5 \mathrm{~m}$ depth $(14,850-14,100$ cal BC, 68.2\%).

ENEA-551. F181n2

$34,300 \pm 3000$

Soil, $22.5 \mathrm{~m}$ depth.

Comment: Ages were used for sheet 181 of the map in Figure 1. Correlation between depth and age is reported in Figure 3c.

\section{Parma Series}

Samples from different sites were collected and submitted in 1995 by P Severi (GSSSERR).

ENEA-431. Gasdotto SNAM

$\mathbf{9 7 3 0} \pm \mathbf{1 5 0}$

Soil from Parma $\left(44^{\circ} 45^{\prime} \mathrm{N}, 10^{\circ} 15^{\prime} \mathrm{E}\right), 1.6$ m depth (9320-9110 cal BC, 36.1\%; 9090-8830 cal BC, $32.1 \%$ ).

ENEA-438. PR181 S2 C2

$19,700 \pm 240$

Soil from Noceto $\left(44^{\circ} 48^{\prime} \mathrm{N}, 10^{\circ} 10^{\prime} \mathrm{E}\right), 3.1 \mathrm{~m}$ depth $(22,000-21,150 \mathrm{cal} \mathrm{BC}, 68.2 \%)$.

ENEA-440. PR199 S2 C1

$\mathbf{3 0 , 8 0 0} \pm 390$

Soil from Collecchio $\left(44^{\circ} 44^{\prime} \mathrm{N}, 10^{\circ} 12^{\prime} \mathrm{E}\right), 25.0 \mathrm{~m}$ depth.

ENEA-441. PR199 S2 C2

$27,500 \pm 400$

Soil from Collecchio, $25.0 \mathrm{~m}$ depth.

Comment: Ages were used for sheets 181 and 199 of the map in Figure 1. 


\section{Ravenna Series}

Samples from Ravenna $\left(44^{\circ} 24^{\prime} \mathrm{N}, 12^{\circ} 12^{\prime} \mathrm{E}\right)$ were collected and submitted in 1996 by P Severi (GSSSERR).

ENEA-447. RA223 S2 n1

$1340 \pm 70$

Soil, $6.0 \mathrm{~m}$ depth (cal AD 630-780, 68.2\%).

ENEA-448. RA223 S2 n2

$2230 \pm 70$

Wood, 7.8 m depth (390-340 cal BC, 16.5\%; 320-200 cal BC, 51.7\%).

ENEA-449. RA223 S2 n3

$8790 \pm 90$

Soil, 25.5 m depth (8170-8110 cal BC, 8.8\%; 7990-7680 cal BC, 58.3\%).

ENEA-552. F240S5n1

$10,650 \pm 130$

Soil, 19.0 m depth (10,890-10,630 cal BC, 56.5\%; 10,520-10,450 cal BC, 11.7\%).

ENEA-553. F240S5n2

$12,500 \pm 220$

Soil, $23.0 \mathrm{~m}$ depth (13,000-12,250 cal BC, 68.2\%).

ENEA-554. F240S5n3

$19,050 \pm 230$

Soil, $31.5 \mathrm{~m}$ depth $(21,000-20,350$ cal BC, 68.2\%).

ENEA-555. F240S6

$19,800 \pm 2200$

Soil, $23.8 \mathrm{~m}$ depth $(23,800-19,800$ cal BC, 66.9\%).

ENEA-557. F240S4n1

$16,900 \pm 140$

Soil, 28.9 m depth (18,230-17,940 cal BC, 68.2\%).

ENEA-558. F240S4n2

$25,400 \pm 1800$

Soil, $34.6 \mathrm{~m}$ depth.

ENEA-561. F240S5n4

$5290 \pm 100$

Soil, 9.5 m depth (4240-3990 cal BC, 68.2\%).

ENEA-562. F240S5n5

$6770 \pm 100$

Soil, 13.0 m depth (5750-5610 cal BC, 60.9\%; 5600-5560 cal BC, 7.3\%).

ENEA-563. F240S3

$11,000 \pm 200$

Soil, $16.5 \mathrm{~m}$ depth $(11,170-10,870 \mathrm{cal}$ BC, 68.2\%).

ENEA-564. F240S4n3

$8800 \pm 140$

Soil, $16.5 \mathrm{~m}$ depth (8200-7650 cal BC, 68.2\%).

Comment: Ages were used for sheets 223 and 240 of the map in Figure 1. Correlation between depth and age is reported in Figure $3 \mathrm{~d}$.

\section{Comacchio Series}

Samples from Comacchio $\left(44^{\circ} 42^{\prime} \mathrm{N}, 12^{\circ} 10^{\prime} \mathrm{E}\right)$ were collected and submitted in $1997-1998$ by P Severi (GSSSERR).

ENEA-502. F205 S9

$2000 \pm 60$

Wood, $8.4 \mathrm{~m}$ depth (60 cal BC-cal AD 80, 64.3\%).

ENEA-503. F205 S4N1

$15,300 \pm 130$

Soil, 34.3 m depth $(16,850-16,630$ cal BC, 68.2\%). 
ENEA-505. F205 S2

$8400 \pm 100$

Peat, $20.5 \mathrm{~m}$ depth (7570-7350 cal BC, 68.2\%).

ENEA-523. F205 S4N2

$1495 \pm 60$

Soil, 8.7 m depth (cal AD 530-650, 64.1\%).

ENEA-586. F205 S7

$10,450 \pm 100$

Soil from Lagosanto $\left(44^{\circ} 45^{\prime} \mathrm{N}, 12^{\circ} 08^{\prime} \mathrm{E}\right), 30.3 \mathrm{~m}$ depth $(10,670-10,490$ cal BC, $29.8 \%$; 10,470$10,210$ cal BC, $38.4 \%)$.

Comment: Ages were used for sheet 205 of the map in Figure 1.

\section{Forlì Series}

Samples from Forlì $\left(44^{\circ} 13^{\prime} \mathrm{N}, 12^{\circ} 02^{\prime} \mathrm{E}\right)$ were collected and submitted in 1997 by $\mathrm{P}$ Severi (GSSSERR).

ENEA-506. F255

$11,350 \pm 130$

Soil, $5.1 \mathrm{~m}$ depth $(11,380-11,150$ cal BC, 68.2\%).

ENEA-530. FO $240 \mathrm{S1}$

$12,000 \pm 150$

Soil, 9.8 m depth (12,080-11,760 cal BC, 68.2\%).

Comment: Ages were used for sheets 255 and 240 of the map in Figure 1.

\section{Cesena Series}

Samples from Cesena $\left(44^{\circ} 08^{\prime} \mathrm{N}, 12^{\circ} 14^{\prime} \mathrm{E}\right)$ were collected and submitted in 1998 by P Severi (GSSSERR).

ENEA-541. FO 255 s5n1

$7690 \pm 100$

Soil, $15.0 \mathrm{~m}$ depth (6610-6450 cal BC, 65.0\%).

ENEA-542. FO $255 \mathrm{s5n} 2$

$14,050 \pm 120$

Soil, $25.8 \mathrm{~m}$ depth $(15,050-14,560 \mathrm{cal} \mathrm{BC}, 68.2 \%)$.

ENEA-544. FO 255 s5n3

$31,000 \pm 5000$

Soil, $35.2 \mathrm{~m}$ depth.

Comment: Ages were used for sheet 255 of the map in Figure 1. Correlation between depth and age is reported in Figure 3e.

\section{Ostellato Series}

Samples from Ostellato $\left(44^{\circ} 44^{\prime} \mathrm{N}, 11^{\circ} 56^{\prime} \mathrm{E}\right)$ were collected and submitted in 1998 by P Severi (GSSSERR).

ENEA-573. F204s6n1

$4010 \pm 60$

Soil, 6.7 m depth (2620-2460 cal BC, 68.2\%).

ENEA-574. F204s6n2

$6900 \pm 70$

Soil, $13.8 \mathrm{~m}$ depth (5850-5710 cal BC, 64.0\%).

Comment: Ages were used for sheet 204 of the map in Figure 1. 


\section{Soliera Series}

Samples from Soliera $\left(44^{\circ} 44^{\prime} \mathrm{N}, 10^{\circ} 55^{\prime} \mathrm{E}\right)$ were collected and submitted in 1999 by P Severi (GSSSERR).

ENEA-575. MO201s4n1

$7780 \pm 110$

Soil, 9.9 m depth (2620-2460 cal BC, 68.2\%).

ENEA-576. MO201s4n2

$12,200 \pm 110$

Soil, $15.7 \mathrm{~m}$ depth $(12,500-11,850 \mathrm{cal} \mathrm{BC}, 68.2 \%)$.

ENEA-577. MO201s4n3

$21,250 \pm 350$

Soil, $24.1 \mathrm{~m}$ depth.

ENEA-578. MO201s4n4

$19,340 \pm 200$

Soil, 21.4 m depth $(21,400-20,650 \mathrm{cal} \mathrm{BC}, 68.2 \%)$.

ENEA-579. MO201s3n1

$14,000 \pm 100$

Soil, $28.7 \mathrm{~m}$ depth $(14,970-14,510 \mathrm{cal} \mathrm{BC}, 68.2 \%)$.

ENEA-580. MO201s3n2

$6890 \pm 80$

Soil, $17.1 \mathrm{~m}$ depth (5880-5700 cal BC, 68.2\%).

Comment: Ages were used for sheet 201 of the map in Figure 1. Correlation between depth and age is reported in Figure 3f.

\section{Argenta Series}

Samples from Argenta $\left(44^{\circ} 36^{\prime} \mathrm{N}, 11^{\circ} 50^{\prime} \mathrm{E}\right)$ were collected and submitted in 2000 by P Severi (GSSSERR).

ENEA-587. F205s1n1

$7550 \pm 70$

Soil, $9.8 \mathrm{~m}$ depth (6480-6360 cal BC, 63.3\%).

ENEA-588. F205s1n2

$25,000 \pm 600$

Soil, $24.5 \mathrm{~m}$ depth.

ENEA-589. F205s1n3

$39,000 \pm 2000$

Soil, $38.8 \mathrm{~m}$ depth.

Comment: Ages were used for sheet 205 of the map in Figure 1. Correlation between depth and age is reported in Figure 3g.

\section{Filo Series}

Samples from Filo $\left(44^{\circ} 35^{\prime} \mathrm{N}, 11^{\circ} 56^{\prime} \mathrm{E}\right)$ were collected and submitted in 2003 by U Cibin (GSSSERR).

ENEA-660. 222-s4 24.4

$23,720 \pm 600$

Soil, 24.4 m depth.

ENEA-674. 222-s4 8.3

$6260 \pm 130$

Soil, 8.3 m depth (5370-5050 cal BC, 68.2\%).

Comment: Ages were used for sheet 222 of the map in Figure 1. 


\section{San Pietro in Casale Series}

Samples from San Pietro in Casale $\left(44^{\circ} 35^{\prime} \mathrm{N}, 11^{\circ} 56^{\prime} \mathrm{E}\right)$ were collected and submitted in 2003 by U Cibin (GSSSERR).

ENEA-661. 203-s1 15.9

$12,640 \pm 160$

Soil, $15.9 \mathrm{~m}$ depth $(13,200-12,500 \mathrm{cal} \mathrm{BC}, 68.2 \%)$.

ENEA-671. 203-s4 21.8

$18,200 \pm 2390$

Soil, $21.8 \mathrm{~m}$ depth.

Comment: Ages were used for sheet 203 of the map in Figure 1.

\section{Castelfranco Emilia Series}

Samples from Castelfranco Emilia $\left(44^{\circ} 35^{\prime} \mathrm{N}, 11^{\circ} 03^{\prime} \mathrm{E}\right)$ were collected and submitted in 2003 by U Cibin (GSSSERR).

ENEA-677. 202-s8 8

$3500 \pm 120$

Wood, 8.0 m depth (1980-1680 cal BC, 66.3\%).

ENEA-684. 202-s8 40.2

Background

Soil, 40.2 m depth.

Comment: Ages were used for sheet 202 of the map in Figure 1.

\section{Navicello Series}

Samples from Navicello $\left(44^{\circ} 40^{\prime} \mathrm{N}, 10^{\circ} 59^{\prime} \mathrm{E}\right)$ were collected in 2002 by A Baio, Acquater SpA, Milano, and P Severi (GSSSERR). P Severi submitted the samples in 2003.

ENEA-685. VI 83 PILA 24-19

$8360 \pm 80$

Soil, $19.0 \mathrm{~m}$ depth (7530-7330 cal BC, 68.2\%).

ENEA-693. VI 83 PILA 24-34

$27,700 \pm 250$

Wood, $34.0 \mathrm{~m}$ depth.

Comment: Ages were used for sheet 202 of the map in Figure 1.

\section{Albareto Series}

Samples from Albareto $\left(44^{\circ} 41^{\prime} \mathrm{N}, 10^{\circ} 58^{\prime} \mathrm{E}\right)$ were collected in 2002 by A Baio, Acquater SpA, Milano, and P Severi (GSSSERR). P Severi submitted the samples in 2003.

ENEA-686. VI 75 PILA 183-8

$2720 \pm 220$

Soil, 8.0 m depth (1250-500 cal BC, 68.2\%).

ENEA-687. VI 75 PILA 181-27.5

$11,100 \pm 160$

Soil, 27.5 m depth $(11,190-10,940$ cal BC, 68.2\%).

ENEA-694. VI 75 PILA 183-10

$1880 \pm 320$

Wood, 10.0 m depth (250 cal BC-cal AD 550, 66.3\%).

ENEA-695. VI 75 PILA 183-14.5

$1700 \pm 120$

Wood, 14.5 m depth (cal AD 210-460, 59.5\%; cal AD 480-540, 8.7\%). 
ENEA-696. VI 75 PILA 181-39

$36,200 \pm 450$

Wood, 39.0 m depth.

Comment: Ages were used for sheet 202 of the map in Figure 1.

\section{Montalbano Series}

Samples from Montalbano $\left(44^{\circ} 46^{\prime} \mathrm{N}, 11^{\circ} 28^{\prime} \mathrm{E}\right)$ were collected and submitted in 2003 by U Cibin (GSSSERR).

ENEA-697. 203-s9n1

$4350 \pm 80$

Soil, $11.45 \mathrm{~m}$ depth (3090-2890 cal BC, 68.2\%).

ENEA-698. 203-s9n2

$13,450 \pm 320$

Soil, 20.25 m depth (14,500-13,500 cal BC, 68.2\%).

Comment: Ages were used for sheet 203 of the map in Figure 1.

\section{Burana Series}

Samples from Burana $\left(44^{\circ} 54^{\prime} \mathrm{N}, 11^{\circ} 21^{\prime} \mathrm{E}\right)$ were collected and submitted in 2004 by P Severi (GSSSERR).

ENEA-711. Burana1

$7030 \pm 200$

Soil, 13.7 m depth (6080-5710 cal BC, 68.2\%).

ENEA-712. Burana2

$4550 \pm 110$

Soil, 5.6 m depth (3500-3450 cal BC, 6.6\%; 3380-3080 cal BC, 61.6\%).

ENEA-713. Burana3

$6290 \pm 60$

Wood, 11.4 m depth (5350-5210 cal BC, 68.2\%).

Comment: Ages were used for sheet 185 of the map in Figure 1.

\section{Pilastri Series}

Samples from Pilastri $\left(44^{\circ} 56^{\prime} \mathrm{N}, 11^{\circ} 17^{\prime} \mathrm{E}\right)$ were collected and submitted in 2004 by P Severi (GSSSERR).

ENEA-714. Pilastri1

$4520 \pm 280$

Wood, $8.0 \mathrm{~m}$ depth (3650-2850 cal BC, 68.2\%).

ENEA-716. Pilastri2

Background

Soil, $32.8 \mathrm{~m}$ depth.

Comment: Ages were used for sheet 184 of the map in Figure 1.

\section{Boretto Series}

Samples from Boretto $\left(44^{\circ} 54^{\prime} \mathrm{N}, 10^{\circ} 33^{\prime} \mathrm{E}\right)$ were collected and submitted in 2004 by P Severi (GSSSERR).

ENEA-729. 182-s1n1

Background

Peat, 33.4 m depth.

ENEA-730. 182-s1n2

$39,900 \pm 650$

Peat, $32.9 \mathrm{~m}$ depth. 
ENEA-731. 182-s1n3

Wood, 19.8 m depth (17,850-17,750 cal BC, 5.5\%; 17,650-17,150 cal BC, 62.7\%).

ENEA-734. 182-s1n4

Soil, 9.0 m depth (7600-7290 cal BC, 65.0\%).

ENEA-735. 182-s1n5

$17,550 \pm 250$

Wood, $22.8 \mathrm{~m}$ depth $(19,150-18,400 \mathrm{cal}$ BC, 68.2\%).

ENEA-736. 182-s1n6

$22,100 \pm 330$

Wood, $23.0 \mathrm{~m}$ depth.

Comment: Ages were used for sheet 182 of the map in Figure 1. Correlation between depth and age of this site (Figure $3 \mathrm{~h}$ ) shows a linear slope quite different from the other sites. This is probably due to the different type of samples dated (wood instead of soil).

\section{Guastalla Series}

Samples from Guastalla $\left(44^{\circ} 55^{\prime} \mathrm{N}, 10^{\circ} 39^{\prime} \mathrm{E}\right)$ were collected and submitted in 2004 by P Severi (GSSSERR).

ENEA-738. Guastalla1

$4930 \pm 80$

Soil, $10.1 \mathrm{~m}$ depth (3800-3630 cal BC, 68.2\%).

ENEA-739. Guastalla2

$4630 \pm 90$

Soil, 10.3 m depth (3630-3590 cal BC, 5.6\%; 3530-3330 cal BC, 54.6\%).

ENEA-740. Guastalla3

$15,450 \pm 130$

Wood, $19.5 \mathrm{~m}$ depth (16,930-16,740 cal BC, 68.2\%).

ENEA-741. Guastalla4

$27,300 \pm 600$

Wood, $34.7 \mathrm{~m}$ depth.

ENEA-742. Guastalla5

Background

Soil, $45.0 \mathrm{~m}$ depth.

ENEA-743. Guastalla6

Background

Soil, 45.3 m depth.

Comment: Ages were used for sheet 183 of the map in Figure 1. 